\title{
Vegetation recolonisation of abandoned agricultural terraces on Antikythera, Greece
}

Carol Palmer, Sue Colledge, Andrew Bevan, and James Conolly

Postprint of a 2010 paper in Environmental Archaeology 15.1: 64-80 (doi: 10.1179/146141010X12640787648973).

\begin{abstract}
Antikythera is a small, relatively remote Mediterranean island, lying $35 \mathrm{~km}$ northwest of Crete and its few contemporary inhabitants live mainly in the small village at the only port. However, an extensive network of terraces across the island bears witness to the past importance of farming on the island although the intensity of use of these cultivated plots has changed according to fluctuating population levels. Most recently, the rural population and intensity of cultivation have dramatically declined. Our aim is to understand the recolonisation process of agricultural land by plants after terraces are no longer used for the cultivation of crops. The results demonstrate a relatively quick pace of vegetative recolonisation, with abandoned farmland covered by dense scrub within 20 to 60 years. The archaeological implications are that following even relatively short periods of abandonment, the landscape would have required arduous reinvestment in the removal of scrub growth, as well as the repair and construction of stone terraces, to allow cultivation once again.
\end{abstract}

\section{Introduction}

Antikythera is a relatively small $\left(20.8 \mathrm{~km}^{2}\right.$, maximum altitude $\left.379 \mathrm{~m}\right)$ and remote Greek island, lying midway between Kythera and western Crete in the southwest Aegean (Fig. 1b). It has had a dynamic history, cycling between periods of relatively substantial population for its size (10-45 people per $\mathrm{km}^{2}$ ) and periods of near complete abandonment. From the late eighteenth century until the earlier part of the twentieth century, it has supported several small villages with an overall population ranging from 300-900 people, based on a mixed, typically Mediterranean, farming economy in which cereals, legumes and vegetables were cultivated alongside some fruit-farming (principally vines but also a few olives), and combined with livestock. All the crops were grown within enclosed fields and terraces, typically in a three-year rotation system including fallow, while sheep and goats grazed the island's rockier slopes. Today, the impressive network of terraces that supported these small communities is largely abandoned: the 30 to 40 current inhabitants no longer practice extensive agriculture. Antikythera's only other wellknown occupants are a large population of feral goats, which are now allowed to roam relatively unconstrained by most such field boundaries, and flocks of birds that use the island as a resting ground on their seasonal migrations between Africa and Europe. 
As the scale of human management of the island's agricultural landscape has declined, the local flora has adapted, recolonising abandoned terraces and enveloping the rocky inclines. This study examines the vegetation that is developing in the abandoned terraces and attempts to determine if the period of abandonment can be estimated based on floristic composition. As such, it therefore represents a contribution to the growing literature on the ecology of old fields (e.g. Cramer and Hobbs 2007), and specifically for the abandonment of former intensively managed landscapes on Mediterranean islands. There is growing awareness and contemporary concern with the loss of biological and culturally-valued diversity that such abandonment represents (Grove and Rackham 2001; Papanastasis 2007; Petanidou et al. 2008; Rackham 2008). Yet, at the same time, many commentators acknowledge that abandonment is also a regular, expected feature of human relationships with ecosystems over the deeper course of time (Rackham and Moody 1996; Grove and Rackham 2001; Cramer and Hobbs 2007, 2). This study therefore also addresses how episodic abandonment affects subsequent recolonisations in terms of landscape appearance and clearance required for renewed occupation and cultivation.

This study is part of a wide-ranging archaeological and environmental survey of the island, directed by Andrew Bevan (UCL) and James Conolly (Trent), which is documenting the long-term human ecology of Antikythera. It is clear from this broader work that the island has experienced similar population cycles, with long periods of near or total abandonment. The island's human history begins with the first substantial exploitation of the island sometime in the later Neolithic (c. 4-5000 cal BC), followed by a series of small farming communities in the Bronze Age. From the end of the second millennium to the mid-fourth century BC there is little trace of human habitation, after which time a large Hellenistic town was founded. If the documentary and archaeological evidence has been correctly interpreted, these Hellenistic inhabitants of Antikythera specialised in piracy to an extent that demanded at least two major military interventions by outside powers and probably led to the town's final destruction in the Roman anti-piracy campaign of the midfirst century BC. After a gap of at least four centuries, the island was re-settled by farmers in the late Roman period, but again this phase of settlement did not last for much longer than two to three hundred years. There is further evidence for renewed small-scale occupation from the twelfth century AD for a century or two before it was again abandoned. Thereafter, it was not extensively occupied until it was recolonised by Sphakiote (west Cretan) families in the later eighteenth century. The current inhabitants are the descendants of these farming families, the villages retain their family names, and the agricultural landscape is most visibly reflective of their early modern agricultural activities. However, the archaeological record suggests, in various interesting ways, that the modern villages and fields map onto the residual traces of early agricultural activities that created re-useable capital (cleared fields, ruined walls, trackways, vestigial orchards, wells, etc.) in the landscape, and which remained attractive structuring features despite what were often centuries of intervening depopulation. 


\section{Antikythera's Terraced Landscape}

Few of the remaining inhabitants on Antikythera have memories of terraces being built on the island (Stellatou n.d.) and, as is the case elsewhere in the Mediterranean, the consensus is that most were constructed prior to the twentieth century (e.g. Grove and Rackham 2001, 107; and for regions neighbouring Antikythera: Price and Nixon 2005; Krahtopoulou and Frederick 2008). The inhabitants consider the terrace systems part of their inheritance from their immediate ancestors (i.e. the most recent colonists from Sphakia) and one that until recently was key to their continued survival as an island community. The central importance of the terraces to agricultural life on Antikythera is reflected by the great care that inhabitants claim was once devoted to their maintenance, without which the terrace walls crumble and their protected soil erodes away, particularly during heavy autumn and winter rains.

Relict agricultural terraces are particularly visible over c. 30\% of Antikythera's 20.8 $\mathrm{km}^{2}$. Stepped, hillslope terraces and cross-channel terraces are the two main types on the island, and other forms such as braided terraces, which zig-zag up a slope, are rare. As has been described in other regions of the Mediterranean, terrace type is often related to underlying geology (Grove and Rackham 2001,107), but can also vary according to different cultural traditions of riser and tread construction (Frederick and Krahtopoulou 2000). On Antikythera, terraces constructed on the hard limestones (e.g. the Upper Cretaceous Rudist bearing Limestone) are generally short, less than $50 \mathrm{~cm}$, and the cultivable fills they bound are thin. On more easily excavated, less dense Tertiary formations, the Neogene marls and Eocene flysch substrata, the terrace walls are taller, often more than $1 \mathrm{~m}$, and the fills substantially deeper.

Soil fertility varies across the island; older current inhabitants report that much of the island was farmed irrespective of the quality of cultivable land. The limestone derived terra rossa soils are water retentive, but often shallow, rocky and difficult to plough. Soils on the Neogene marls and on the few pockets of Eocene flysch that exist are both easier to work (particularly by hand) than the terra rossa soils; the Neogene marl derived soils, however, are often less fertile than the other two dominant soil types (C. Frederick pers. comm.). Agricultural records from the period of the early nineteenth century British administration clearly document a phase of rapid agricultural expansion from the 1820-40s in which the amount of declared land under crop rose from $7 \%$ to $43 \%$ of total island area and more marginal areas became increasingly exploited (UK National Archives Colonial Office 136, boxes 1332-1390). Apart from a very brief influx of hundreds of refugees from Crete, the population hovered around 3-400 people during this period. The most recent process of terrace abandonment seems to have started fairly abruptly when most of the able-bodied population of the island was forced to move to Crete by occupying German authorities during Second World War. After the war, agricultural life resumed to a degree, but appears never fully to have recovered, with cereal farming largely disappearing by the late 1980s and early 90s, and only a few scattered vegetable gardens and vineyards continuing to be maintained today. Cultivated plots 
are usually fenced to protect crops from the island's feral goat population, estimated to number up to 3,000 (Stellatou n.d.). These goats were released into the landscape during the recent depopulation. Today, the goats are not managed but are regularly hunted.

\section{Aims, Materials and Methods}

Our analysis concentrated on characterising the differences in vegetation at six representative locations on the island. More specifically, we wished to understand the recolonisation of agricultural land by plants once terraces are no longer used for cultivation of crops or grazing livestock. The ultimate aim was to assign a relative age of abandonment for terraces that had fallen into disuse.

The botanical work on Antikythera was undertaken over five days in April 2008. Antikythera is connected to Kythera and Crete, its larger neighbours, via an infrequent ferry service, and our first attempt to conduct this vegetation survey in March/April 2007 was unsuccessful due to inclement weather. Fieldwork in 2008 was also curtailed by similar problems, but in our view the resulting sample is nonetheless still sufficiently large to offer some important insights.

We adopted a Braun-Blanquet inspired semi-quantitative, relevé method (MuellerDombois and Ellenberg 1974) to explore the vegetation at our six main areas of interest on the island. The position of each sample vegetation quadrat (or relevé) was carefully chosen with the aim of finding a representative sample that could characterise the area under investigation as a whole. In selecting each area, we worked in close collaboration with the project's geoarchaeologist, Charles Frederick, and so were able to take into account and accurately describe local geological and edaphic parameters. From interviews with local inhabitants conducted by Anna Stellatou in 2007, we could also take into account the relative importance ascribed by the island's farmers to the different agricultural areas.

For each quadrat, a list of taxa was made and coverage of each taxon estimated using the 'extended Braun-Blanquet cover abundance scale' (Table 1, see also Barkman et al. 1964). Our survey areas at each location were defined by quadrats ranging in size between $30 \times 30 \mathrm{~m}$ and $10 \times 10 \mathrm{~m}$, dependent on the relative diversity of the flora (i.e. larger quadrats for lower species diversity, and vice versa). As well as botanical, geological and edaphic information, we also recorded terrace type, slope, aspect and UTM co-ordinates. Given the time constraints of our work on the island this method represents a relatively rapid and efficient method of vegetation survey with the results suitable for analysis using numerical techniques such as ordination and classification. The data were analysed using the ordination technique of correspondence analysis (Gauch 1982; Jongman et al. 1995).

The vegetation groupings studied on Antikythera can broadly be classified into cultivated land (vineyards and horticultural plots); terraces with herbaceous vegetation (Fig. 2), phrygana and low maquis; and unterraced land dominated by low or high maquis. In this survey phrygana vegetation is defined as low vegetation 
cover, less than $50 \mathrm{~cm}$ tall, dominated by spaced, spiny and aromatic cushionshaped shrubs (Margaris 1981; Margaris et al. 1984; Turland and Fielding 2005, 33). Maquis defines denser, often more impenetrable scrub, usually including the presence of evergreen sclerophylls, shrubs with small, thick, leathery evergreen leaves. Low maquis is defined here as less than $c .1 \mathrm{~m}$ in height and tall or true maquis is above $1 \mathrm{~m}$ and is where evergreen sclerophylls are more likely to be a dominant component. Seasonal dimorphism involving the shedding and growth of different types of branches and leaves is the key physical feature of phryganic shrubs (Margaris 1981), reflected in the origin of the word phrygana from the Greek for 'dry firewood or twigs' (Turland and Fielding 2005, 33). However, it should be noted that phryganic shrubs of this growth form (woody chaemophytes) also grow as components of maquis vegetation, and frequently dominate low maquis as defined here (the western Mediterranean term 'garrigue' is also used, e.g. Turland and Fielding 2005), while evergreen sclerophylls grow in phrygana, although usually far less frequently. In summary, the two physical types of shrub grow together and grade into each other as different vegetation formations, with a transitional form between phrygana and maquis (Papanastasis and Kazaklis 1998, 142), and with both physical types of plant representing woody adaptations to water stress during the summer drought.

In total 13 quadrat plots were studied in six localities encompassing the island's main geological forms and soil types: Charchaliana (at the northwest of the island), Kokkinos Lakos (northeast), Liziana (north-central), Galaniana (south-central), Agios Georgios (southeast) and Domata East (south) (Fig. 1a, Table 2). A majority of the quadrats were situated on terraces, in addition we surveyed one area in a vineyard and as a control to our study we defined two quadrats on unterraced land (i.e. these were areas that were unbounded by terrace walls and which showed no signs of having been farmed).

At three of the terraces we established that there had been relatively recent use of the land either for arable farming or as pasture for livestock: at Charchaliana (Q12) there was an abundance of relatively 'fresh' dung and the presence of sheep grazing in a nearby field attested to the current use of the area; in the plot at Agios Georgios (Q 13) old vines with leafy growth, which had not completely withered and died, indicated recent tending of the vineyard; and at Galaniana (Q9) we were fortunate to be able to talk to a local farmer who told us that the terrace we surveyed was cultivated within the past 20 years.

In total 120 taxa were recorded in 13 quadrats (Table 3). Botanical nomenclature follows Flora Europaea (Tutin et al. 2001) and Turland et al. (1993); we made reference also to a recent floristic and phytosociological investigation of the island (Tzanoudakis et al. 2006).

\section{Results}

i) Taxon diversity and composition 
The most ubiquitous perennials in the quadrats are the typical phryganic seasonally dimorphic shrubs (i.e. with different summer branch and leaf forms): Sarcopoterium spinosum (nine quadrats), Coridothymus (Thymus) capitatus (eight) and Psorelea bituminosa (eight). Other phryganic species occurring in three or more quadrats are Calicotome villosa (four), Genista acanthoclada (four), Helichrysum barrelieri (four), Satureja nervosa (four) and Prasium majus (three). Pistacia lentiscus is the most constantly encountered evergreen schlerophyllous shrub, occurring in six quadrats, with Quercus coccifera and Juniperus phoenicea each recorded once. Smilax aspera, a creeping or scrambling thorny shrub, is the only other evergreen schlerophyllous species, and it occurs in three quadrats. Other frequently encountered perennials (herbaceous and semi-herbaceous) are Dorycnium hirsutum, Urginea maritima, Convolvulus althaeoides, Reichardia picroides, Mandragora autumnalis and Muscari comosum. In total, 46 perennial taxa were recorded, plus two biennial/perennial taxa, one species that can grow both as an annual and a perennial, Anthyllis vulneraria subsp. rubriflora (though included in the calculations as a perennial), and the biennial Tragopogon porrifolius.

The main annual taxa represented are members of the Fabaceae, Asteraceae and Poaceae families. The most common annual identified is Hypochoeris achyrophorus (seven quadrats), followed by Linum trigynum, Scorpiurus muricatus, Ononis reclinata, Anagallis arvensis, Trifolium campestre, Valantia hispida and Trigonella balansae; all occurring in four or more quadrats. In total 57 annual taxa were recorded. Thirteen taxa could not be identified to a sufficient level to distinguish life form due to insufficient characteristics available for secure identification.

Table 4 presents the number of different taxa recorded in each plot. In six quadrats the taxon count is higher than the mean (mean count: 22): quadrats $12,5,6,10,1$ and 2; these include both quadrats surveyed on unterraced land (Domata East 2 and Kokkinos Lakos 5) and the recently pastured land at Charchalania (Q12), which has highest count of all 13 quadrats. The other plots with higher than average counts are at Galaniana (Q10), Liziana (Q6) and Domata East (Q1); these were on terraces that we presumed had been subject to longer-term abandonment. When the numbers of taxa recorded are calculated per $10 \mathrm{~m}^{2}$, five quadrats are well above the mean (mean=4.96): Q6, 9, 10,12,13; significantly, these comprise all three plots on land we have assumed was cultivated in the recent past.

Assessment in terms of taxon diversity appears to demonstrate that there is correlation with land use; for example, diversity is higher both on plots that were recently farmed and in areas that were unterraced, and which showed no evidence of having been cultivated. It could be concluded that once terraces have been abandoned there is a reduction in diversity but after a further period of time species richness increases.

Table 5 presents proportions of taxa per quadrat according to life form. Four quadrats have more annuals than perennials: $12,6,9$ and 13, and these comprise the plots we considered to be in current use or to have been used in the recent past. 
As with the assessment by taxon diversity, Q12 at Charchaliana is outstanding in having by far the highest ratio of annuals to perennials. On all other quadrats perennials outnumber annuals, including those at Kokkinos Lakos 5 and Domata East 2, where we could discern no evidence for cultivation.

Consideration of taxon counts alone did not allow for distinction between the most recently used land and the uncultivated areas but, taken in conjunction with an assessment of life form, there appears to be a clear disparity according to the relative proportions of annual and perennial taxa. For example, annuals outnumber perennials on plots that we assumed to have been used in the recent past, whereas perennials are predominant on the unterraced land. In this respect the vegetation recorded on the terrace at Liziana (Q6) is characteristic of that defined for recently cultivated areas. Quadrats 1 and 10, which had high taxon diversity, also have relatively high proportions of annuals (a ratio of 0.91 annuals to perennials) but there is little to distinguish between the quadrats on other terraces, which had low diversity and were dominated by perennials.

ii) Multivariate analysis of the dataset

The correspondence analysis confirms these trends and further clarifies the relationship between length of time since abandonment and overall species composition. Fig. 3 presents the graphical output for an analysis of a dataset comprising presence/absence data in the 13 quadrats for 120 taxa identified during the survey. In this sample plot Q12 (the recently grazed Charchaliana terrace) is an outlier and its position at one extreme of axis 1 is indicative of a very different species composition to that of the other quadrats (which all cluster at the opposite extreme of axis 1). This is perhaps no surprise given the taxon diversity for the quadrat is the highest recorded in the survey. Exclusion of Q12 from the dataset results in a much more evenly distributed spread of samples along axes 1 and 2 (Fig. 4). Most noticeable is the fact that the quadrats on the recently used areas ( 9 and 13 ) and those on unterraced land ( 2 and 5 ) are at either extreme of axis 1 , with the other terraces positioned between the two.

To explore compositional differences, the correspondence analysis was repeated on a dataset of relative abundance scores for the 120 taxa in 12 quadrats (Q12 is omitted), and the 120 taxa were grouped according to life form (e.g. annuals, perennials, annuals/biennials/perennials, or unknown). The resulting sample plot (Fig. 5) was drawn using pie charts for each sample showing the proportional contribution of each life form. The distribution of quadrats in the relative abundance plot (Fig. 5) was very similar to that in the presence/absence plot (Fig. 4). Higher proportions of perennial taxa characterise the quadrats to the left of axis 1 , whereas the number of annuals is greater in the quadrats to the right of the axis. This dichotomy was noted in the earlier statistical assessment of proportionality of taxa but is strikingly obvious in this analysis: there is a much greater presence of annuals in the recently used plots and, conversely, perennials are dominant in the unterraced areas. The gradual change in proportions of perennials versus annuals in the other quadrats from right to left along axis 1 may reflect stages in recolonisation 
once these terraces had fallen into disuse. Axis 1 could thus represent the time line for length of time of abandonment, with the surveyed plots to the right of axis 1 having been abandoned for a shorter period of time than those to the left of the axis.

To assist in the identification of possible 'indicator species' at either end of the spectrum of land use (or disuse) represented in the set of plots we surveyed taxa were classified on the basis of: those present on the recently used land (i.e. quadrats Galaniana 9 and Agios Georgios 13); those recorded on the unterraced plots (i.e. quadrats 2 and 5); those common to both these sets of quadrats; and those taxa only found on the other terraces (the outlier quadrat, Charchaliana 12, was again excluded from this exercise). A total of 68 taxa ( $57 \%$ of the total) were represented in the two sets of quadrats located on recently used and on unterraced land, and seven of these were common to both (see Table 3). From the portrayal of these data in bar chart form (Fig. 6), in this instance using presence/absence of taxa rather than relative abundance, and arranged in descending order from left to right according to the percentage presence of those taxa common to recently used terraces, it is clear that the ranking of the quadrats closely matches their position along axis 1 in the CA plots (Figs. 4 and 5). Most significant in this figure is the existence of a group of taxa (i.e. labelled as 'other taxa' in the chart) that characterise the middle of the cline, between the two extremes of recent land-use and long-term neglect, which are represented in those quadrats where there was thought to have been a longer period of abandonment.

We are able to distinguish taxa that favour recently cultivated land from those that are probably characteristic of the later stages of recolonisation after abandonment. The woody perennial species, especially the phryganic species Sarcopoterium spinosum and Coridothymus capitatus, establish well soon after abandonment. Sarcopoterium is adapted both to overgrazing and to wildfires, with its ability to resprout after grazing and with seeds that germinate after burning (Papanastasis 2007, 237). Quercus coccifera is also resistant to grazing and fire, but is only established in one of the quadrats studied here; of the sclerophyllous evergreens Pistacia lentiscus is more prevalent, perhaps due to its maintenance along terrace walls. After the stage when Sarcopoterium and Coridothymus dominate, other nonpillow-like phryganic species (e.g. Genista acanthoclada and Calicotome villosa) start to colonise, thus increasing diversity. Woody species then cover most of the areas within a short period.

Most of the annuals grow in the vicinity of the phrygana plants. Koutsidou and Margaris $(1998,78)$ note that in the first stages of succession the Poaceae decreased at the expense of other families but the Fabaceae remained stable and especially in more degraded areas. In our study it is striking that taxa from the Fabaceae family are dominant rather than grasses (26 Fabaceae versus 7 Poacaea).

iii) Comparison of overall vegetation cover

In addition to our semi-quantitative study we also carried out a subjective assessment of the overall cover in terms of the major vegetation types (e.g. higher 
maquis, low maquis, phrygana and herbaceous growth) in each quadrat. For this we gave an estimated $\%$ cover for each type (Table 6 ). The vegetation on all the recently used plots (and including Q6 at Liziana) is dominated by herbaceous taxa whereas, with the exception of Q8 at Kokkinos Lakos, phyrgana is predominant on those terraces we have assumed were subject to long term neglect (e.g. quadrats, 10, 1, 11, 7,4 and 3). Low maquis is dominant on the unterraced plot at Domata East 2 and this vegetation type is present in the quadrats to the left of axis 1 in our correspondence plots, i.e. which are apparently further along the chronological cline of abandonment than those to the right of the axis. In this respect the overall cover on the terrace at Kokkinos Lakos (Q8) is similar to that defined for the uncultivated land, as it too is dominated by low maquis. High maquis forms only a minor component of the vegetation in two areas: Kokkinos Lakos 2 and 5. Fig. 7 illustrates these differences clearly: the quadrats are arranged from left to right in descending order of proportional cover of low maquis and ascending order of herbaceous cover, these being the two vegetation types that most obviously define the extremes of land use (or disuse) in our study.

We established that the recently cultivated terraces were still in use up to 20 years ago. We are unsure of the date of abandonment of the other terraces, but our knowledge of the recent history of the island suggests this to have been since the Second World War. Therefore, on Antikythera perennial vegetation cover, beginning with phrygana, appears to dominate abandoned terrace vegetation 20 to 60 years after cultivation ceases (Fig. 8). This is broadly in accord with similar vegetation studies on other Aegean islands, which suggest that perennials start to dominate after 20 years and can form up to 90\% of biomass after 30-40 years (Giourga et al. 1998; Koulouri and Giourga 2007).

\section{Discussion}

Recently abandoned terraces contain a relatively rich, low herbaceous flora and on longer abandoned terraces there is a transformation of the vegetation into a more typical phrygana type, where small pillow mounds of Sarcopoterium and Cordiothymus dominate. Diversity decreases as length of time of abandonment increases, but after a much longer period of disuse it would appear that species richness increases again, though the composition of the recolonised land is markedly different to that of the original fields. In recently abandoned terraces the numbers of annuals are high, whereas in unterraced areas low maquis, which comprises many perennial species, is dominant. After longer term abandonment the proportion of annual species seems to decrease as perennials invade and become established. Colonisation of perennials onto terraces that are no longer cultivated is likely to be affected by the presence of potential species along terrace walls and in former intensively grazed land alongside them (Fig. 9).

In summary, our research shows the conversion of former agricultural terraces through an herbaceous phase to phrygana to low maquis (garrigue). This trend to woody species on abandoned agricultural land reflects a widespread pattern of vegetation regeneration observed elsewhere in the Mediterranean basin (Giourga et 
al. 1998; Grove and Rackham 2001; Papanastasis 2007; Tzanopoulous et al. 2007). The establishment of low, pillow-like phryganic species, especially Sarcopoterium spinosum, is a common feature of relatively recently abandoned terraces on Mediterranean islands (Giourga et al. 1998; Papanastasis 2007). Maquis, including Quercus coccifera, Juniperus phoenicea and Pistacia lentiscus, establishes in the longer term, and it has been proposed that this occurs after 30-40 years; we would concur but suggest perhaps a slightly longer time span of between 20-60 years.

A number of authors warn it should not be assumed that the vegetation returns to exactly the same form as it would have had before it was managed and that succession may be variable (Tzanopoulos et al. 2005, 27; Rackham 2008, 58). Two factors affect succession: adaptation to aridity, with woody species dominating in Mediterranean landscapes, and with annuals and grasslands more prevalent in wetter climates such as in northern Greece (see, for a review, Papanastasis 2007); and livestock grazing.

Antikythera's vegetation continues to be browsed by feral goats and grazing pressure is known to affect the rate of regeneration. If grazing is excluded, annuals are initially favoured over perennials (Koutsidou and Margaris 1998) but the succession is only modified and not prevented (Papanastasis 2007, 238). Based on a study of the island of Sifnos, Tzanopoulous et al. $(2007,374)$ suggest that Pistacia lentiscus and Juniperus phoenicea come to dominate after 20 years with light grazing pressure and after 30-40 years with high grazing intensity. It is unclear to what extent grazing has impacted the vegetation succession on Antikythera.but, once established, perennials are known to reduce the edible biomass (Margaris 1987 in Giourga et al. 1998, 593) thus, as the succession progresses, there are likely to be implications for the carrying capacity of the goat population.

A further factor that affects vegetation regeneration is wood-cutting by the human population for construction and fuel, for example, Juniperus phoenicea was once the preferred material for roof construction as is clearly visible in abandoned housing on the island (Fig. 10). As with cultivation, wood-cutting has now almost completely ceased on Antikythera and the cessation of this activity, like grazing, also favours woody perennials.

\section{Conclusion}

Our survey has demonstrated that the rate of vegetation succession is rapid and in the space of one to three generations dense scrub replaces cultivated land. Therefore, following episodes of abandonment, each of which lasted a few centuries, new settlers on the island will have encountered a landscape showing signs of past human habitation (e.g. terrace and field walls and abandoned stone structures), but not the previously cultivated fields. The recolonisation of the landscape would involve reinvesting in the built structures, such as stone terraces, and also removal of scrub growth on earlier farmed land. The timber and brushwood cleared from the overgrown plots would have been a useful resource as fuel and thatching, and also as feed for livestock, and should thus be considered as a valuable product for the 
coloniser families. Nevertheless, land clearance necessitates considerable time and labour investment before fields become viable for grain crops, which suggests that colonisation required some pre-planning and/or contact with off-island groups to ensure that there were sufficient food stocks to sustain the first year or more of settlement. Given the level of investment needed to return the island to a cultivated landscape was substantial, we propose that prior to any permanent reoccupation the island was more likely to have been used for less labour-intensive subsistence activities, such as hunting or foddering for semi-managed herds of goats, associated with shorter term visits probably during the spring/summer months when sea travel is less prone to interruptions by storms. The interaction between plant and human communities is an important feature of the ecology of Antikythera which we suggest has parallels on other Mediterranean landscapes that also undergo similar sequences of abandonment and recolonisation. 


\section{Acknowledgements}

We would like to thank the Greek Ministry of Culture, the Greek Archaeological Service (26th EPKA, 1st EBA) and the Greek Institute for Geology and Mining, as well as our three primary external funding agencies over the duration of the overall Antikythera Survey Project-the Social Science and Humanities Research Council (SSHRC) of Canada, the UK Arts and Humanities Research Council (AHRC) and the Institute for Aegean Prehistory (INSTAP). Dedicated funding for this work in particular was provided through an AHRC Landscape and Environment small grant (AH/E502989/1). Our sponsor in Athens has been the Canadian Institute in Greece and we are grateful to Jonathan Tomlinson for his assistance throughout. Aris Tsaravopoulos offered extremely helpful guidance at various stages. We thank Charles Frederick for his valuable insights into the geology of Antikythera, Anna Stellatou for her ethnographic observations and Glynis Jones for her comments on the data analysis. At the time of writing, the digital datasets upon which this analysis is based can be accessed from the ASP website at either www.ucl.ac.uk/asp or www.tuarc.trentu.ca/asp and will be archived more permanently with the UK Archaeological Data Service (www.ahds.ads.ac.uk). They are also available from the authors upon request.

\section{References:}

Barkman, J. J., Doing, H. and Segal, S. 1964. Kritische bemerkungen und vorschläge zur quantitativen vegetationsanalyse. Acta Botanica Neerlandica 13, 394-419.

Cramer, V. A. and Hobbs, R. J. 2007. Old Fields: Dynamics and Restoration of Abandoned Farmland. Washington (D.C.): Island Press.

Frederick, C. and Krahtopoulou, A. 2000. Deconstructing agricultural terraces; examining the influence of construction method on stratigraphy, dating and archaeological visibility, pp. 79-94 in Halstead, P. and Frederick, C. (eds.), Landscape and Landuse in Postglacial Greece. Sheffield: Sheffield Academic Press.

Gauch, H. G. 1982. Multivariate Analysis in Community Ecology. Cambridge: Cambridge University Press.

Giourga, H., Margaris, N. S. and Vokou, D. 1998. Effects of grazing pressure on succession process and productivity of old fields on Mediterranean islands. Environmental Management 22(4), 589-596.

Grove, A. T. and Rackham, 0. 2001. The Nature of Mediterranean Europe: An Ecological History. Yale: Yale University Press.

Jongman, R. H. G., ter Braak, C. J. and van Tongeren, O. F. R. 1995. Data Analysis in Community and Landscape Ecology. Cambridge: Cambridge University Press. 
Koulouri, M. and Giourga, C. 2007. Land abandonment and slope gradient as key factors of soil erosion in Mediterranean terraced lands. Catena 69, 274-281.

Koutsidou, E. and Margaris, N. S. 1998. The regeneration of Mediterranean vegetation in degraded ecosystems as a result of grazing pressure exclusion: the case of Lesvos island, pp. 76-79 in Papanastasis, V. P. and Peter, D. (eds.), Ecological Basis of Livestock Grazing in Mediterranean Ecosystems. Luxembourg: Office for Official Publications of the European Communities.

Krahtopoulou. A. and Frederick, C. 2008. The stratigraphic implications of long-term terrace agriculture in dynamic landscapes: polycyclic terracing from Kythera Island, Greece. Geoarchaeology 23, 550-585.

Margaris, N. S. 1981. Adaptive strategies in plants dominating Mediterranean-type ecosystems, pp. 309-315 in di Castri, J. and Specht, R. L. (eds.), Mediterranean-type Shrublands. Ecosystems of the World 11. Amsterdam: Elsevier.

Margaris, N. S., Adamandiadou, S., Siafaca, L. and Diamantopoulos, J. 1984. Nitrogen and phosphorus content in plant species of Mediterranean ecosystems in Greece. Vegetatio 55, 29-35.

Mueller-Dombois, D. and Ellenberg, H, 2002. Aims and Methods of Vegetation Ecology. Caldwell (N.J.): The Blackburn Press.

Papanastasis, V. P. 2007. Land abandonment and old field dynamics in Greece, pp. 225-246 in Cramer, V. A. and Hobbs, R. J. (eds.), Old Fields: Dynamics and Restoration of abandoned farmland. Washington (D.C.): Island Press.

Papanastasis, V. P. and Kazaklis, A. 1998. Land use changes and conflicts in the Mediterranean-type ecosystems of western Crete, pp. 141-154 in Rundel, P. W., Mentenegro, G. and Jaksic, F. M. (eds.), Landscape Disturbance and Biodiversity in Mediterranean-Type Ecosystems. Ecological Studies 136. Berlin: Springer.

Petanidou, T., Kizos, T. and Soulakellis, N. 2008. Socioeconomic dimensions of changes in the agricultural landscape of the Mediterranean Basin: a case study of the abandonment of cultivation terraces on Nisyros Island, Greece. Environmental Management 41, 250-266.

Price, S. and Nixon, L. 2005. Ancient Greek agricultural terraces: evidence from texts and archaeological survey. American Journal of Archaeology 109, 665-694.

Rackham, 0. 2008. Holocene history of Mediterranean island landscapes, pp. 36-60 in Vogiatzakis, I. N., Pungetti, G. and Mannion, A. M. (eds.), Mediterranean Island Landscapes: Natural and Cultural Approaches. Dordrecht: Springer. 
Rackham, O. and Moody, J. A. 1996. The Making of the Cretan Landscape. Manchester: Manchester University Press.

Stellatou, A. (n.d.) Antikythera Survey Project: Ethnographic Research Report. Unpublished document in possession of the authors.

Turland, N. J., Chilton, L. and Press, J. R. 1993. Flora of the Cretan Area: Annotated Checklist and Atlas. London: HMSO, The Natural History Museum.

Turland, N. J. and Fielding, J. 2005. Flowers of Crete. Kew: Royal Botanic Gardens.

Tutin, T.G, Heywood, V. H., Burges, N. A, Valentine, D.H., Walters, S. M., and Webb, D. A. 2001. Flora Europaea. Cambridge: Cambridge University Press.

Tzanoudakis, D., Panitsa, M., Trigas, P. and Iatrou, G. 2006. Floristic and phytosociological investigation of the island Antikythera and nearby islets (SW Aegean, Greece). Willdenowia 36, 285-301.

Tzanopoulos, J., Mitchley, J. and Pantis, J. 2005. Modelling the effects of human activity on the vegetation of a northeast Mediterranean island. Applied Vegetation Science 8, 27-38.

Tzanopoulos, J., Mitchley, J. and Pantis, J. 2007. Vegetation dynamics in abandoned crop fields on a Mediterranean island: Development of succession model and estimation of disturbance thresholds. Agriculture, Ecosystems and Environment 120, 370-3. 


\section{Figures}

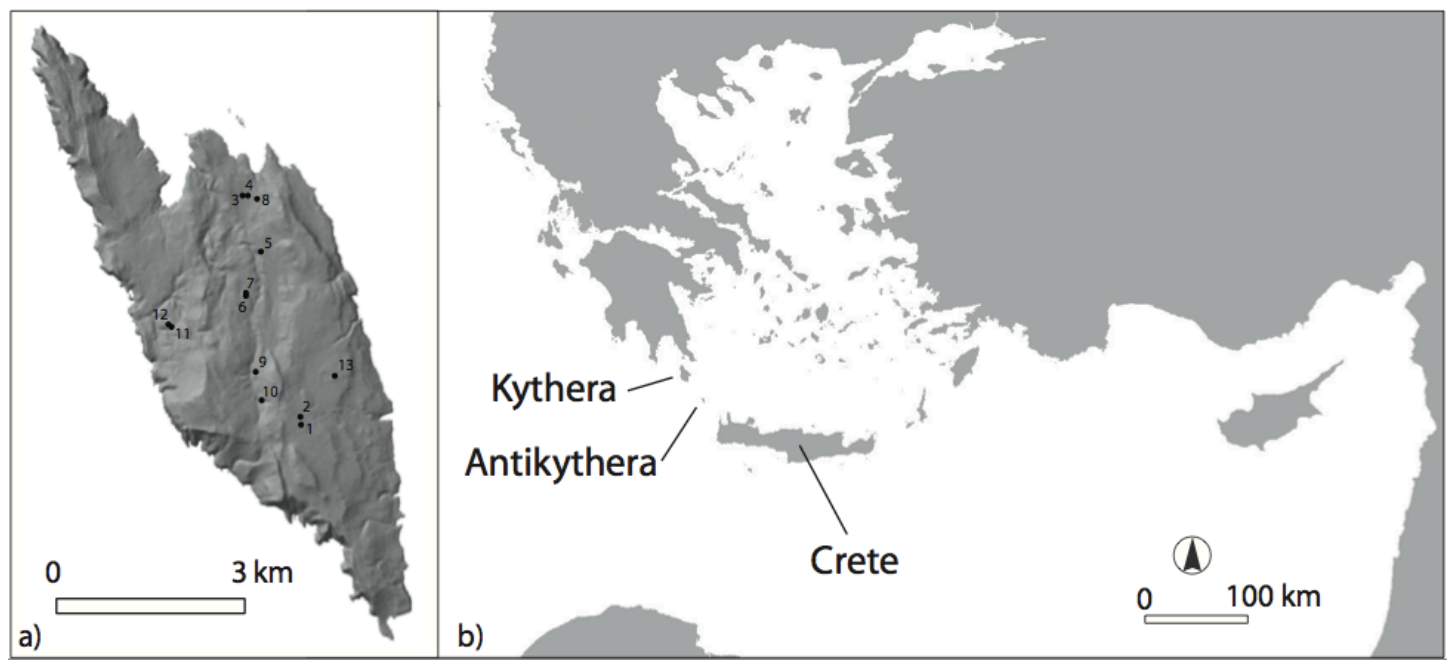

Figure 1. Maps showing a) quadrat locations b) location of Antikythera

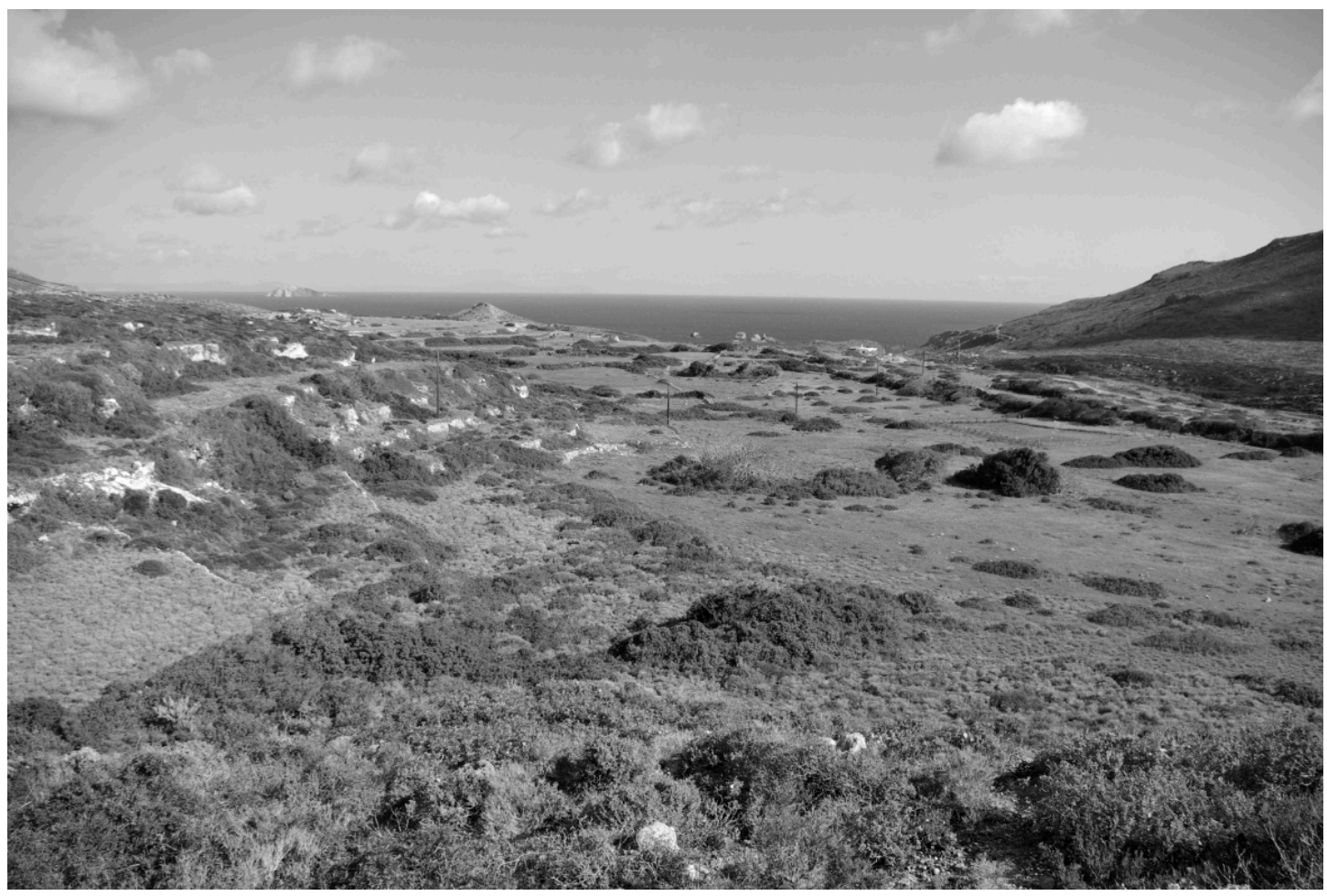

Figure 2. View looking north from Liziana area showing a small fenced horticultural plot surrounded by herbaceous vegetation (to the right), and abandoned terraces covered with phyrganic vegetation and evergreen shrubs (to the left and foreground) 


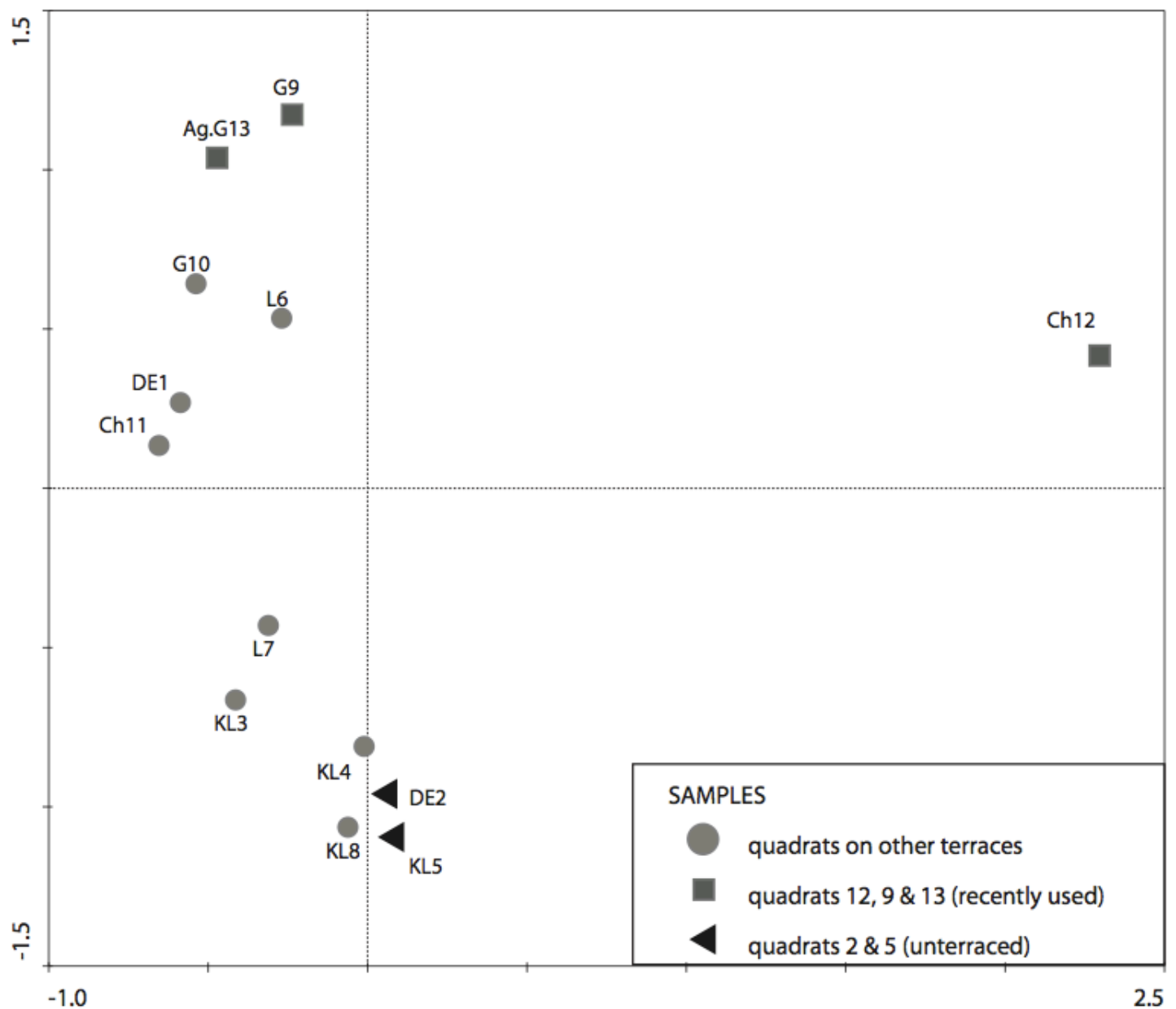

Figure 3. CA plot for the dataset comprising presence/absence data for 120 taxa identified in the 13 quadrats 


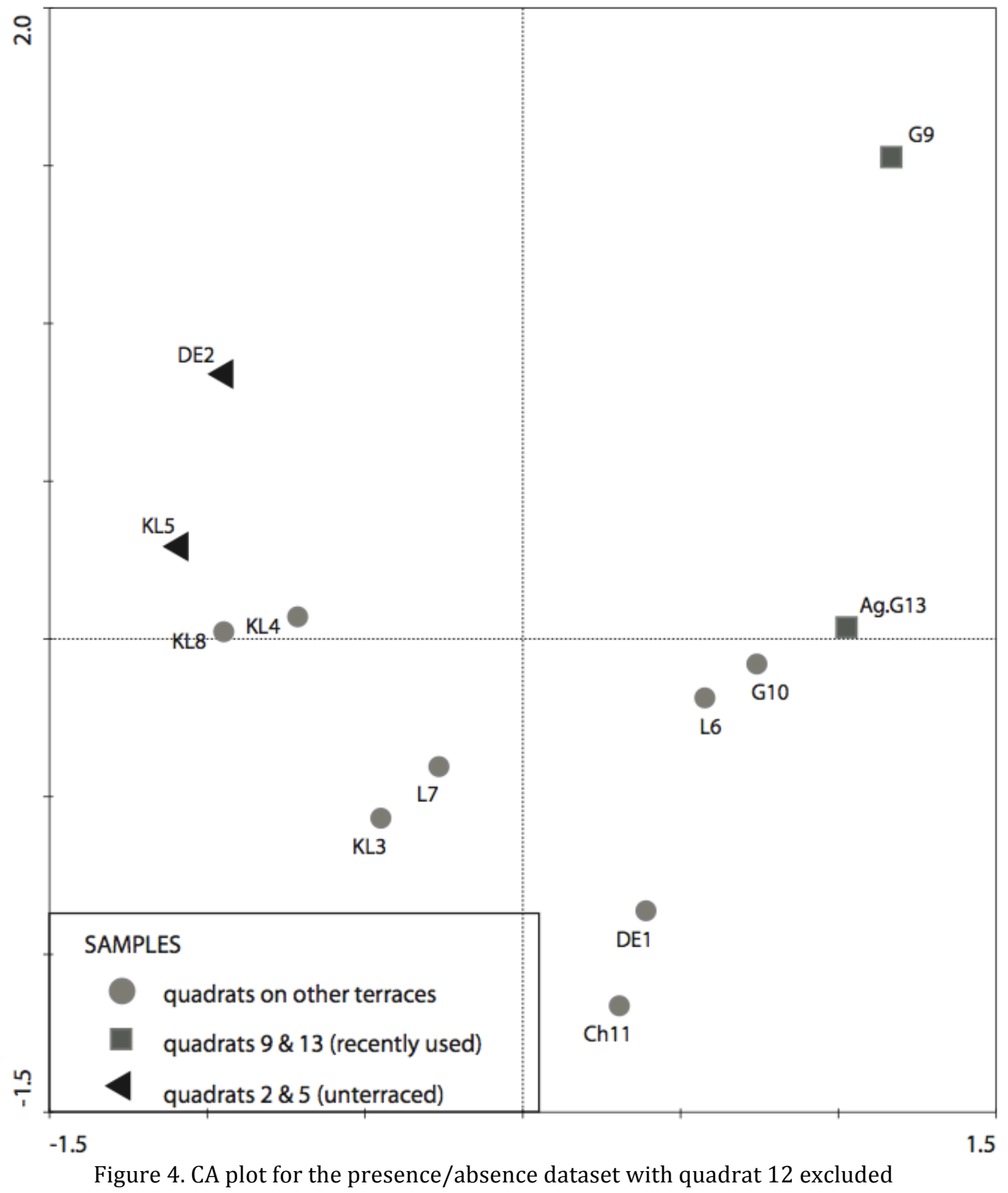




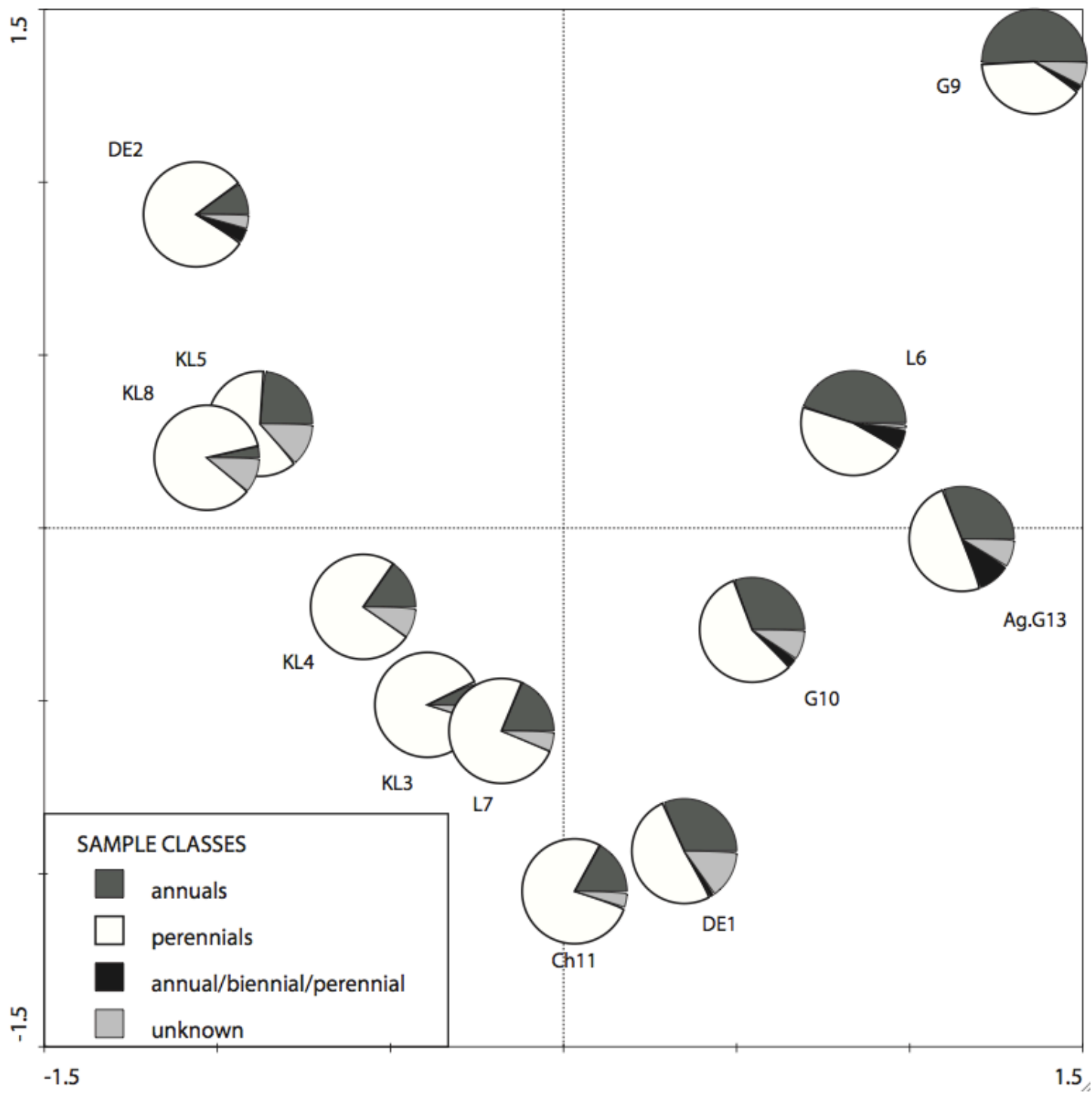

Figure 5. Fig. 4 redrawn using pie charts to show the proportional representation of the different life forms in each quadrat 


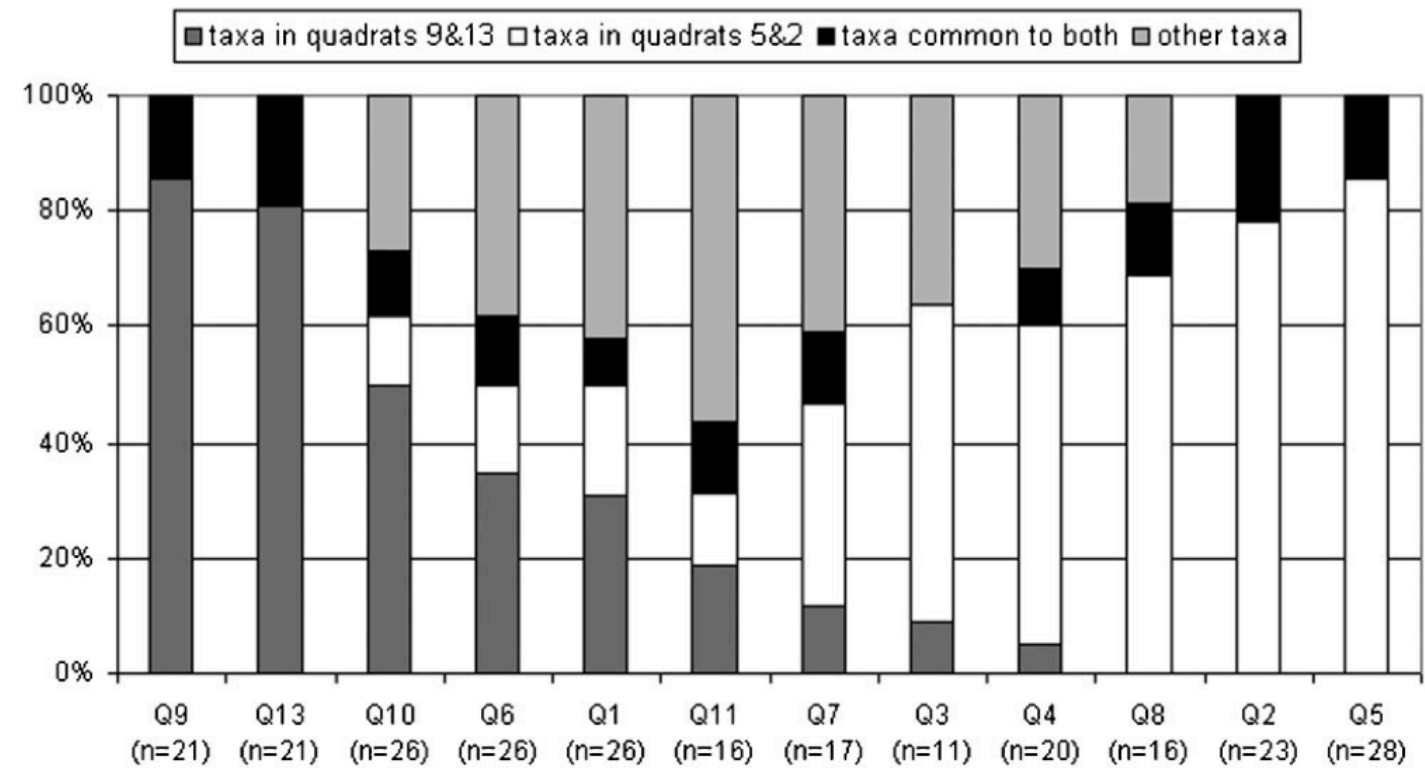

Figure 6. Bar charts showing presence/absence data for the taxon groupings shown in Fig. 5 arranged in descending order from left to right along the $\mathrm{x}$ axis according to the percentage presence of those taxa common to recently used terraces ( $\mathrm{n}=$ number of taxa identified)

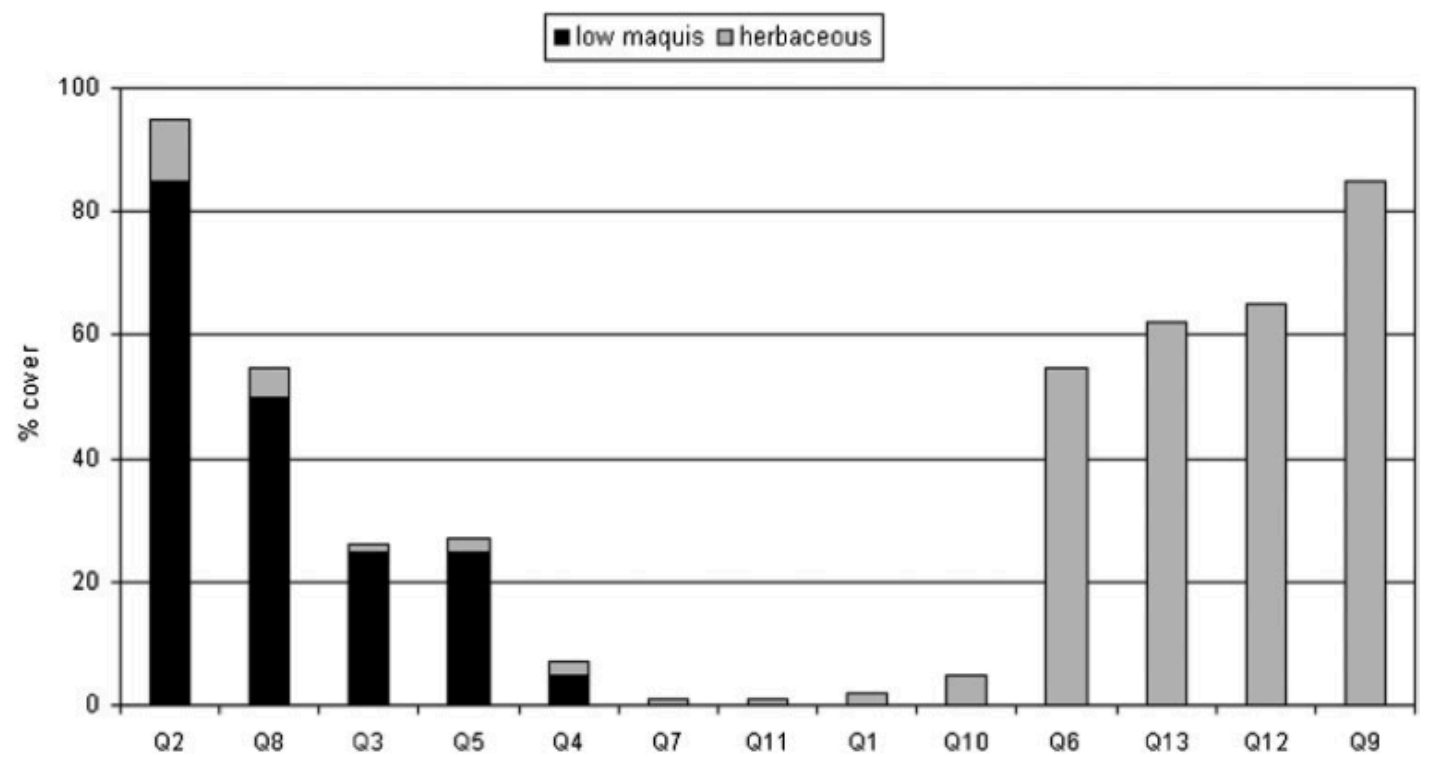

Figure 7. Bar charts showing percentage cover for the two vegetation types that define the extremes of land use in our study arranged along the $\mathrm{x}$ axis in descending order of low maquis and ascending order of herbaceous vegetation 

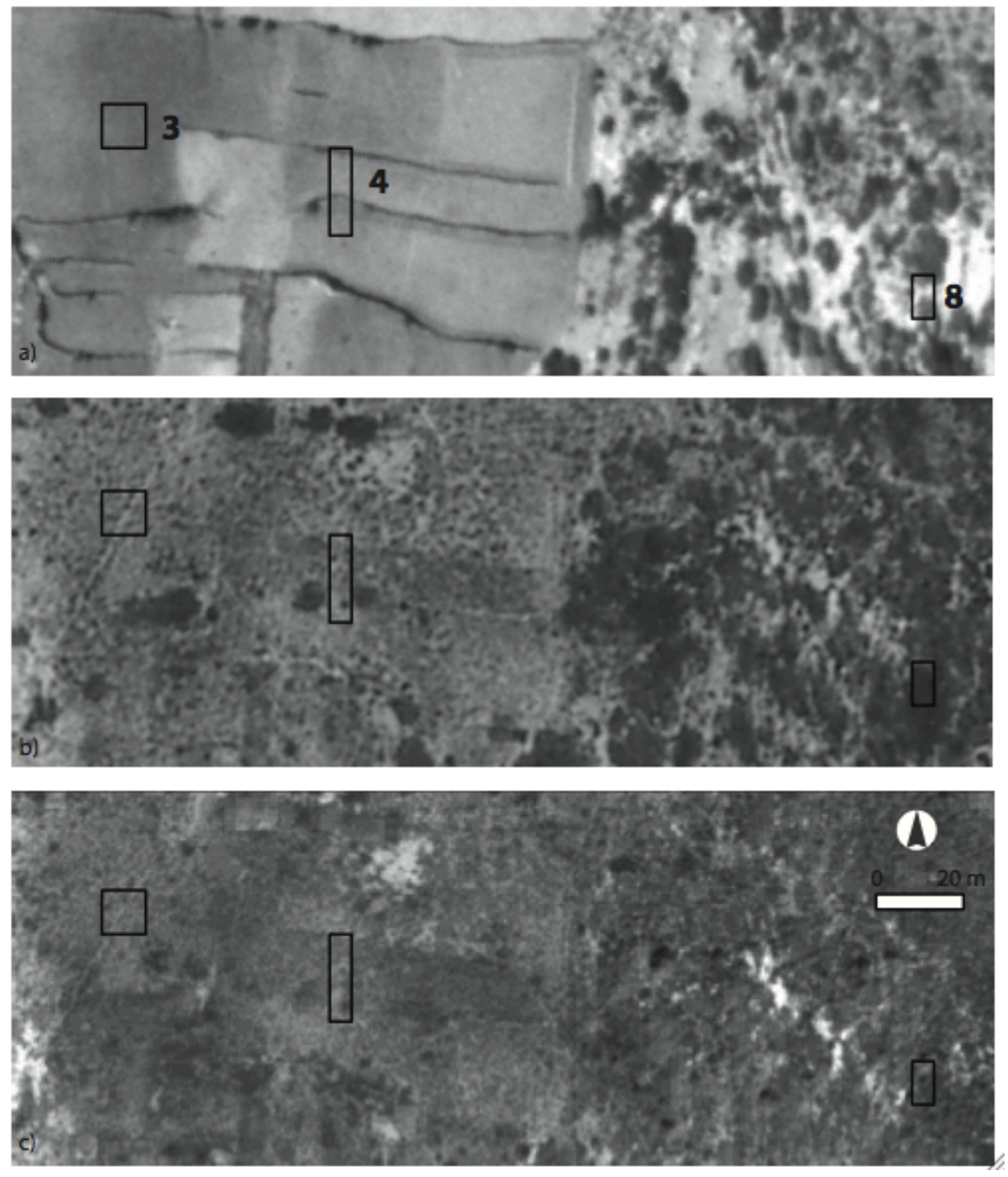

Figure 8. Close-up aerial view of the vegetation around quadrats 3, 4 and 8 showing stages of colonization of phrygana and maquis, as visible in a) an aerial photo from March 1944 (top), b) an aerial photo from August 1988 (centre), and c) a Quickbird panchromatic image from September 2004 (bottom) (courtesy of the Aerial Reconnaissance Archive, the Hellenic Military Geographical Service and Digital Globe/Eurimage, respectively) 


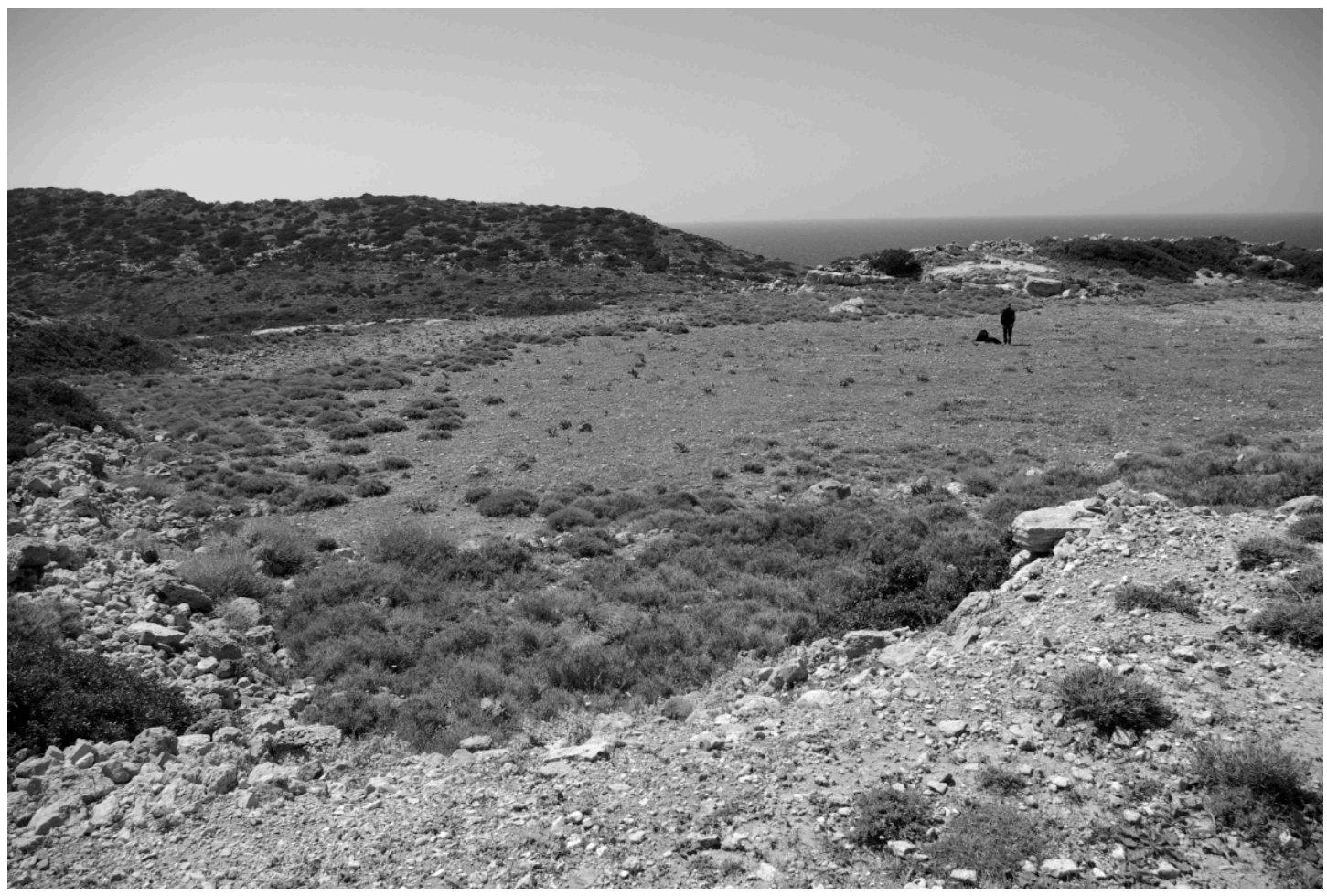

Figure 9. Encroaching phrygana on quadrat 12 at Charchaliana

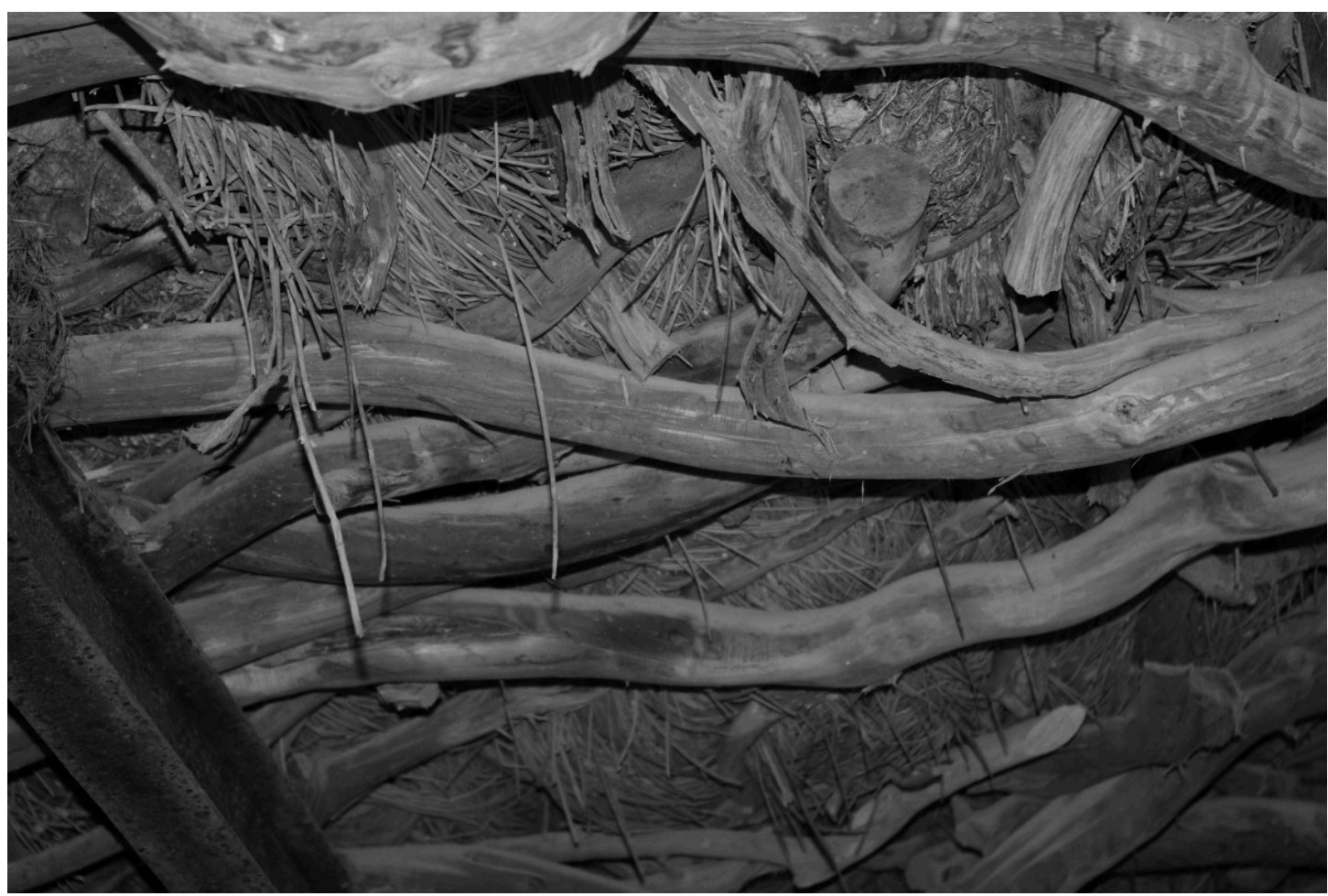

Figure 10. Wooden roof beams of juniper (Juniperus phoenicea) in an abandoned building 


\begin{tabular}{|l|l|l|}
\hline Score & $\begin{array}{l}\text { Estimated number of } \\
\text { individuals or } \\
\text { estimated \% cover }\end{array}$ & $\begin{array}{l}\text { Value in } \\
\text { statistical } \\
\text { analyses }\end{array}$ \\
\hline$r$ (rare) & 1 & 1 \\
\hline+ & $2-5$ & 2 \\
\hline 1 & $6-50$ & 3 \\
\hline $2 \mathrm{~m}$ & $>50$ & 4 \\
\hline $2 \mathrm{a}$ & $5-15 \%$ & 5 \\
\hline $2 \mathrm{~b}$ & $16-25 \%$ & 6 \\
\hline 3 & $26-50 \%$ & 7 \\
\hline 4 & $51-75 \%$ & 8 \\
\hline 5 & $76-100 \%$ & 9 \\
\hline
\end{tabular}

Table 1. The extended Braun-Blanquet cover abundance scale (Barkman et al. 1964); in the statistical analyses the scale was converted to a numeric scale

\begin{tabular}{|c|c|c|c|c|c|c|}
\hline & Charchaliana & Domata East & Galaniana & $\begin{array}{c}\text { Kokkinos } \\
\text { Lakos }\end{array}$ & Liziana & $\begin{array}{c}\text { Agios } \\
\text { Georgios }\end{array}$ \\
\hline Ur Cretacous Terra Rossa & & quadrats 1,2 & & quadrats $3,4,5$ & & \\
\hline Neogene derived terrace soil & quadrats 11,12 & & & & quadrats 6,7 & \\
\hline Neogene/Ur Cretaceous transition Terra Rossa & & & & quadrat 8 & & \\
\hline Flysch/Terra Rossa on Ur Cretaceous & & & quadrats 9,10 & & & \\
\hline Eocene/Flysch & & & & & & quadrat 13 \\
\hline
\end{tabular}

Table 2. Location of the thirteen quadrats according to their position on the island and to the underlying geology 


\begin{tabular}{|c|c|c|c|c|c|c|c|c|c|c|c|c|c|c|c|c|c|}
\hline Taxa & Life form & 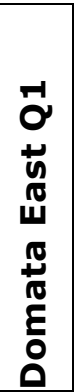 & 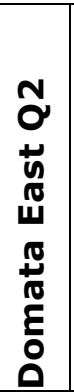 & 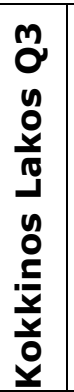 & 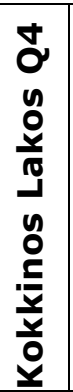 & 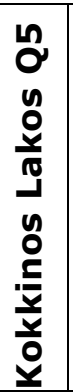 & 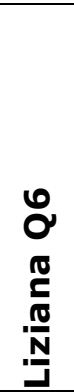 & $\begin{array}{l}\hat{O} \\
\mathbb{0} \\
\frac{0}{0} \\
\frac{N}{N}\end{array}$ & 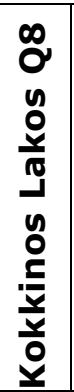 & 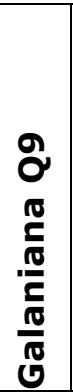 & 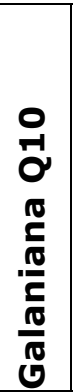 & 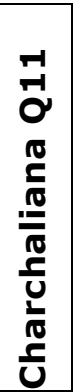 & 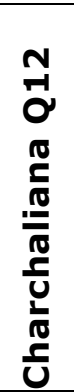 & 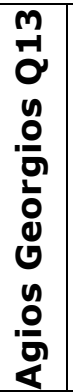 & 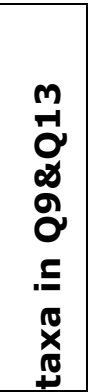 & 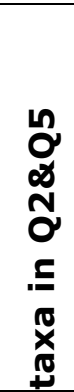 & 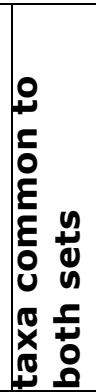 \\
\hline Adonis cf. microcarpa & annual & & & & & & $\mathrm{r}$ & & & & & & & & & & \\
\hline Allium sp. & perennial & & + & & $r$ & & & & & & & & & & & $\checkmark$ & \\
\hline Anacamptis pyramidalis & perennial & & & & 1 & & & + & & & & & & & & & \\
\hline Anagallis arvensis & annual & & $\mathrm{r}$ & & & & & 1 & & & & & 1 & + & & & $\checkmark$ \\
\hline Anchusa variegata & annual & & & & & & & & & & & & + & & & & \\
\hline Anthyllis tetraphylla & annual & & & & & & & & & & & $r$ & & & & & \\
\hline Anthyllis vulneraria subsp. rubriflora & annual/perennial & 1 & & 1 & & & & & & & & + & & & & & \\
\hline Asphodelus aestivus & perennial & & + & & & & & & & & & & & & & $\checkmark$ & \\
\hline Avena sp. & annual & & & & & & $2 a$ & & & 4 & $r$ & & & & $\checkmark$ & & \\
\hline Bellevalia sp. & perennial & & & & & 1 & & & & & & & & & & $\checkmark$ & \\
\hline Biscutella didyma & annual & & & & & $r$ & & & & & & & & & & $\checkmark$ & \\
\hline Brassicaceae indet. & annual & & & & & & & & & & & & $r$ & & & & \\
\hline Bromus diandrus & annual & & & & & & & & & & & & + & & & & \\
\hline Bromus sp. & annual & & & & & & & & & & & & $r$ & & & & \\
\hline Calendula arvensis & annual & & & & & & & & & & & & 1 & & & & \\
\hline Calicotome villosa & perennial & & $2 a$ & + & $2 a$ & $2 a$ & & & & & & & & & & $\checkmark$ & \\
\hline Campanula erinus & annual & & & & & & & & & & & & + & & & & \\
\hline Carex sp. & perennial & 1 & & & & & & & & & & & & & & & \\
\hline Chondrilla juncea & perennial & & $r$ & & + & $r$ & & & & & & & & & & $\checkmark$ & \\
\hline Cistus creticus & perennial & & + & & & & & & + & & & & & & & $\checkmark$ & \\
\hline Convolvulus althaeoides & perennial & $2 m$ & + & & & & 1 & & & & 1 & & & 3 & & & $\checkmark$ \\
\hline Coridothymus capitatus & perennial & & + & $2 \mathrm{~b}$ & 4 & 3 & + & 5 & 3 & & & 4 & & & & $\checkmark$ & \\
\hline Crupina crupinastrum & annual & & & & $r$ & $r$ & & & & & & & & & & $\checkmark$ & \\
\hline Cynara cornigera & perennial & & $\mathrm{r}$ & & & & & & & & & & & & & $\checkmark$ & \\
\hline
\end{tabular}


Dorycnium hirsutum
Erica cf. manipuliflora

Erodium cf. gruinum

Euphorbia sp. 1

Euphorbia sp. 2

Evax pygmaea

Ferula communis

\section{Filago pyramidata}

Fumana cf. arabica

Galactites tomentosa

\section{Galium sp.}

Genista acanthoclada

Geranium robertianum

Gladiolus italicus

Gynandriris sisyrinchium

Hedypnois cretica

Hedysarum spinosissimum

Helichrysum barrelieri

Hippocrepis unisiliquosa

Hymenocarpos circinnatus

Hyoseris scabra

Hypericum empetrifolium

Hypericum triquetrifolium

Hypochoeris sp.

Hypochoeris achyrophorus

Juniperus phoenicea

Lagurus ovatus

Lathyrus sp.

Linum trigynum

Lolium sp.

Lotus cf. ornithopodioides/peregrinus

Lotus cytisoides

Lotus edulis

Mandragora autumnalis

Medicago cf. rigidula

Medicago coronata

\begin{tabular}{|c|c|c|c|c|c|c|c|c|c|c|c|c|c|c|c|c|}
\hline perennial & 1 & & 1 & 1 & & & + & $r$ & & + & 1 & & & & & \\
\hline perennial & & & & & & & & $2 b$ & & & & & & & & \\
\hline annual & & & & & & & & & & & & + & & & & \\
\hline annual & & & & & & $r$ & & & & & & & & & & \\
\hline annual & & & & & 1 & 1 & & & & & & & & & $\checkmark$ & \\
\hline annual & & + & & & & & & & & & & & & & $\checkmark$ & \\
\hline perennial & & & & & & & & & & & & & + & $\checkmark$ & & \\
\hline annual & & & & & & & & & & & & + & & & & \\
\hline perennial & & & & & & & & 1 & & & & & & & & \\
\hline annual & & & & & & & & & & & & 1 & & & & \\
\hline annual & & & & & & & & & & & & + & & & & \\
\hline perennial & & 3 & $2 b$ & & $2 a$ & & & 3 & & & & & & & $\checkmark$ & \\
\hline annual/biennial & & 1 & & & & & & & & & & + & & & $\checkmark$ & \\
\hline perennial & & & & & & & & & $r$ & $2 \mathrm{~m}$ & & & & $\checkmark$ & & \\
\hline perennial & & & & & & & & & $r$ & & & & & $\checkmark$ & & \\
\hline annual & & & & & & $r$ & & & & & & & & & & \\
\hline annual & & & & & & 1 & & & & & & & + & $\checkmark$ & & \\
\hline perennial & & & $r$ & & & + & $2 a$ & & & & 1 & & & & & \\
\hline annual & 1 & & & & & $r$ & & & & & & & + & $\checkmark$ & & \\
\hline annual & 1 & & & & & & & & & $r$ & & & + & $\checkmark$ & & \\
\hline annual & & & & & & & & & & & & 1 & & & & \\
\hline perennial & & & & & & & + & & & + & & & & & & \\
\hline perennial & & & & & & $r$ & & & & & & & & & & \\
\hline annual & & & 1 & 1 & 1 & + & 1 & + & & 1 & & & & & $\checkmark$ & \\
\hline annual & & & & & $r$ & & & & & & & & & & $\checkmark$ & \\
\hline perennial & & & & & + & & & & & & & & & & $\checkmark$ & \\
\hline annual & & & & & & & & & & & & 1 & & & & \\
\hline annual & & & & & & & & & & & & & $r$ & $\checkmark$ & & \\
\hline annual & & & & + & 1 & 1 & $r$ & & & & & + & $r$ & & & $\checkmark$ \\
\hline annual & & & & & & & & & + & & & & & $\checkmark$ & & \\
\hline annual & 1 & & & & & & + & & 1 & & & & & $\checkmark$ & & \\
\hline perennial & & & & & & & & & & & 1 & & & & & \\
\hline annual & $r$ & & & & & & & & & & $r$ & & & & & \\
\hline perennial & $r$ & & & $r$ & $r$ & & & $r$ & & & & 1 & & & $\checkmark$ & \\
\hline annual & & & & & & & & & 1 & + & & & & $\checkmark$ & & \\
\hline annual & & & & $r$ & & + & & & & & & & & & & \\
\hline
\end{tabular}


\begin{tabular}{|l} 
Medicago orbicularis \\
Medicago polymorpha
\end{tabular}

Medicago rugosa

Medicago sp. 1

Medicago sp. 2

Medicago sp. 3

Muscari comosum

\section{Muscari sp.}

Nepeta sp.

Ononis reclinata

\section{Ophrys sp.}

Ornithogalum sp.

Orobanche sp.

Oxalis sp.

Pallenis spinosa

Phagnalon graecum

Phlomis fruticosa

Pistacia lentiscus

\section{Plantago lagopus}

Poaceae (vegetative)

Poaceae indet. 1

Prasium majus

Psoralea bituminosa

Quercus coccifera

Reichardia picroides

Rostraria cristata

Sanguisorba minor subsp. verrucosa

Sarcopoterium spinosum

Satureja nervosa

Scorpiurus muricatus

Sherardia arvensis

Smilax aspera

Tetragonologus purpureus

Teucrium sp.

Tordylium apulum

Tragopogon porrifolius

\begin{tabular}{|c|c|c|c|c|c|c|c|c|c|c|c|c|c|c|c|c|}
\hline annual & $r$ & & & & & & & & & & & & & & & \\
\hline annual & & & & & & $r$ & & & & & & & & & & \\
\hline annual & & & & & & & & & $r$ & & & & & $\checkmark$ & & \\
\hline annual & + & & & & & & & & & & $r$ & & & & & \\
\hline annual & & & & & & & & & 1 & & & & & $\checkmark$ & & \\
\hline annual & + & & & & & & & & & & & & & & & \\
\hline perennial & & & & + & & 1 & & & + & & & 1 & & $\checkmark$ & & \\
\hline perennial & & & & $r$ & & & & & & & & & & & & \\
\hline perennial & & & & & & & & & & & & + & & & & \\
\hline annual & 1 & & & $r$ & + & & & $r$ & & & & & & & $\checkmark$ & \\
\hline perennial & & & & & & & $r$ & & & & & & & & & \\
\hline perennial & & r & & & & & & & & & & & & & $\checkmark$ & \\
\hline perennial & & & & & & & & & $r$ & & & & 1 & $\checkmark$ & & \\
\hline perennial & + & & & & & $2 b$ & & & 5 & $2 b$ & & & 4 & $\checkmark$ & & \\
\hline annual/biennial & $r$ & & & & & + & & & & $r$ & & & 1 & $\checkmark$ & & \\
\hline perennial & & & & & & & & & & & & & + & $\checkmark$ & & \\
\hline perennial & & + & & & 1 & & & & & & & & & & $\checkmark$ & \\
\hline perennial & & $2 b$ & & & $2 a$ & & & $2 a$ & & + & + & & r & & & $\checkmark$ \\
\hline perennial & & & & & & & & & & & & $2 a$ & & & & \\
\hline perennial & 1 & $2 b$ & 1 & $2 a$ & $2 \mathrm{~m}$ & & + & $2 a$ & & $2 m$ & & & & & $\checkmark$ & \\
\hline annual & & & & & & & & & & & & + & & & & \\
\hline perennial & & $2 a$ & & & + & & 1 & & & & & & & & $\checkmark$ & \\
\hline perennial & 1 & & $2 a$ & & & 3 & $2 a$ & & $2 a$ & + & 1 & & $2 \mathrm{~b}$ & $\checkmark$ & & \\
\hline perennial & & 4 & & & & & & & & & & & & & $\checkmark$ & \\
\hline perennial & $r$ & & & & & + & & & & $r$ & + & & & & & \\
\hline annual & & & & & & & & & & & & + & & & & \\
\hline perennial & & & & & & 1 & & & & & & & & & & \\
\hline perennial & 4 & $r$ & 3 & $2 b$ & 1 & & + & + & & 5 & $2 a$ & & & & $\checkmark$ & \\
\hline perennial & 1 & & & & & & + & & & + & $r$ & & & & & \\
\hline annual & 1 & & & & + & + & & & $r$ & $2 a$ & $r$ & & & & & $\checkmark$ \\
\hline annual & & & & & & & & & & & & + & & & & \\
\hline perennial & & & & & 1 & & $r$ & $2 a$ & & & & & & & $\checkmark$ & \\
\hline annual & & & & & & & & & & + & & & + & $\checkmark$ & & \\
\hline perennial & & & & $r$ & & & & & & & & & & & & \\
\hline annual & & & & & & & & & + & & & + & & $\checkmark$ & & \\
\hline biennial & & & & & & + & & & $r$ & $r$ & & & 1 & $\checkmark$ & & \\
\hline
\end{tabular}




\begin{tabular}{|c|c|c|c|c|c|c|c|c|c|c|c|c|c|c|c|c|c|}
\hline Trifolium campestre & annual & + & & & & & & & & & + & 1 & & 1 & $\checkmark$ & & \\
\hline Trifolium repens type & annual & & $r$ & & & & & & & $r$ & & & & & & & $\checkmark$ \\
\hline Trifolium sp. & annual & & & & & & & & & & & & & + & $\checkmark$ & & \\
\hline Trifolium stellatum & annual & & & & & & + & & & & & & + & & & & \\
\hline Trigonella balansae & annual & & & & & & & & & 1 & $r$ & & + & $r$ & $\checkmark$ & & \\
\hline Urginea maritima & perennial & & 1 & & $r$ & 1 & & & 1 & + & & & + & & & & $\checkmark$ \\
\hline Urospermum picroides & annual & & & & & $r$ & & & & & & & $r$ & & & $\checkmark$ & \\
\hline Valantia hispida & annual & & 1 & & & 1 & $r$ & & & & & & $2 m$ & & & $\checkmark$ & \\
\hline Vicia cf. parviflora & annual & $r$ & & & $\mathrm{r}$ & & & & & & + & & & & & & \\
\hline Vicia sativa & annual & & & & & & & & & & $\mathrm{r}$ & & & & & & \\
\hline Vicia sp. & annual & + & & & & & & & & & & & & & & & \\
\hline Apiaceae indet. & unknown & & & & & + & & & + & & & & & & & $\checkmark$ & \\
\hline Asteraceae (vegetative) & unknown & + & & & & & $r$ & & & $r$ & + & + & & 1 & $\checkmark$ & & \\
\hline Asteraceae (yellow) indet. 1 & unknown & & & & $2 m$ & $2 m$ & & & 1 & & & & $2 m$ & & & $\checkmark$ & \\
\hline Asteraceae (yellow) indet. 2 & unknown & & & & & & & & & + & & & & & $\checkmark$ & & \\
\hline Asteraceae (yellow) indet. 3 & unknown & 1 & 1 & & & & & & & & & & & & & $\checkmark$ & \\
\hline Astragalus sp. & unknown & & & & & & & & & $r$ & $r$ & & & + & $\checkmark$ & & \\
\hline Convolvulus sp. & unknown & & & & & r & & & & & & & & & & $\checkmark$ & \\
\hline Erodium sp. & unknown & & & & & & & & & & & & + & & & & \\
\hline Lotus sp. & unknown & & & + & & & & & & & & & & & & & \\
\hline Plantago sp. & unknown & & & & & & & & & & 1 & & & & & & \\
\hline Scrophulariaceae indet. & unknown & & & & & & & & & & & & r & & & & \\
\hline Indet. & unknown & & & & & & & 1 & & & & & & & & & \\
\hline Indet. & unknown & & & & & $r$ & & & & & & & & & & $\checkmark$ & \\
\hline
\end{tabular}

Table 3. Braun-Blanquet cover abundance scale (see Table 1) for the 120 taxa represented in the 13 quadrats; botanical nomenclature follows Flora Europaea (Tutin et al. 2001) and Turland et al. (1993); taxa represented in quadrats 9 and 13 (recently used terraces) and in quadrats 2 and 5 (unterraced land), together with those common to both sets of plots, are also indicated 


\begin{tabular}{|c|c|c|c|c|c|}
\hline $\begin{array}{l}\frac{\pi}{\pi} \\
\frac{\pi}{0} \\
\frac{\pi}{2} \\
\frac{\pi}{\sigma}\end{array}$ & location & geology/soil & 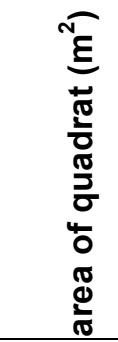 & 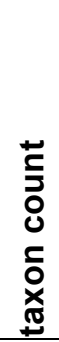 & 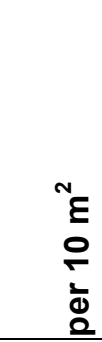 \\
\hline 1 & Domata East & Upper Cretaceous/Terra Rossa & 100 & 26 & 2.60 \\
\hline 2 & Domata East & Upper Cretaceous/Terra Rossa & 125 & 23 & 1.84 \\
\hline 3 & Kokkinos Lakos & Upper Cretaceous/Terra Rossa & 100 & 11 & 1.10 \\
\hline 4 & Kokkinos Lakos & Upper Cretaceous/Terra Rossa & 100 & 20 & 2.00 \\
\hline 5 & Kokkinos Lakos & Upper Cretaceous/Terra Rossa & 125 & 28 & 2.24 \\
\hline 6 & Liziana & Neogene limestone derived & 25 & 26 & 10.40 \\
\hline 7 & Liziana & Neogene limestone derived & 50 & 17 & 3.40 \\
\hline 8 & Kokkinos Lakos & $\begin{array}{l}\text { Neogene + Upper Cretaceous/Terra } \\
\text { Rossa }\end{array}$ & 50 & 16 & 3.20 \\
\hline 9 & Galaniana & Upper Cretaceous/flysch or Terra Rossa & 25 & 21 & 8.40 \\
\hline 10 & Galaniana & Eocene Flysch & 37.5 & 26 & 6.93 \\
\hline 11 & Charchaliana & Neogene limestone derived & 100 & 16 & 1.60 \\
\hline 12 & Charchaliana & Neogene limestone derived & 25 & 31 & 12.40 \\
\hline 13 & Agios Georgios & Eocene Flysch & 25 & 21 & 8.40 \\
\hline & & & mean & 22 & 4.96 \\
\hline
\end{tabular}

Table 4. Taxon counts per quadrat and per $10 \mathrm{~m}^{2}$ for each location 


\begin{tabular}{|c|c|c|c|c|c|c|}
\hline $\begin{array}{l}\frac{\pi}{\pi} \\
\frac{\pi}{0} \\
\frac{\pi}{2} \\
\frac{\sigma}{\sigma}\end{array}$ & location & $\begin{array}{l}\overline{\bar{\sigma}} \\
\frac{c}{c} \\
\frac{c}{\sigma}\end{array}$ & 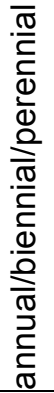 & 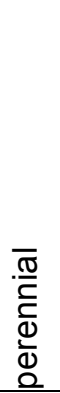 & $\begin{array}{l}\frac{5}{3} \\
\frac{0}{5} \\
\frac{5}{5} \\
\frac{5}{5}\end{array}$ & 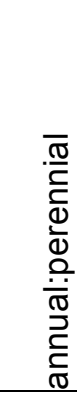 \\
\hline 1 & Domata East & 10 & 1 & 11 & 4 & 0.91 \\
\hline 2 & Domata East & 4 & 1 & 17 & 1 & 0.24 \\
\hline 3 & Kokkinos Lakos & 1 & 0 & 9 & 1 & 0.11 \\
\hline 4 & Kokkinos Lakos & 5 & 0 & 13 & 2 & 0.38 \\
\hline 5 & Kokkinos Lakos & 9 & 0 & 14 & 5 & 0.64 \\
\hline 6 & Liziana & 14 & 2 & 9 & 1 & 1.56 \\
\hline 7 & Liziana & 4 & 0 & 12 & 1 & 0.33 \\
\hline 8 & Kokkinos Lakos & 1 & 0 & 12 & 3 & 0.08 \\
\hline 9 & Galaniana & 10 & 1 & 7 & 3 & 1.43 \\
\hline 10 & Galaniana & 10 & 2 & 11 & 3 & 0.91 \\
\hline 11 & Charchaliana & 5 & 0 & 10 & 1 & 0.50 \\
\hline 12 & Charchaliana & 22 & 1 & 5 & 3 & 4.40 \\
\hline 13 & Agios Georgios & 10 & 2 & 7 & 2 & 1.43 \\
\hline
\end{tabular}

Table 5. Numbers of taxa according to life form, and ratios of annuals to perennials, for each quadrat 


\begin{tabular}{|c|c|c|c|c|c|c|c|c|}
\hline $\begin{array}{l}\frac{\pi}{\pi} \\
\frac{\pi}{0} \\
\frac{\pi}{2} \\
\sigma\end{array}$ & location & 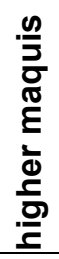 & $\begin{array}{l}\frac{n}{J} \\
\bar{\sigma} \\
\mathbb{0} \\
E \\
3 \\
\underline{0}\end{array}$ & 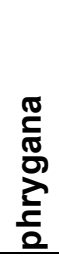 & 은 & 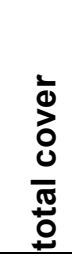 & 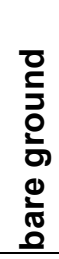 & dominant taxon \\
\hline 1 & Domata East & 0 & 0 & 70 & 2 & 72 & 28 & Sarcopoterium spinosum \\
\hline 2 & Domata East & 0 & 85 & 0 & 10 & 95 & 5 & Quercus coccifera \\
\hline 3 & Kokkinos Lakos & 0 & 25 & 45 & 1 & 71 & 29 & Sarcopoterium spinosum \\
\hline 4 & Kokkinos Lakos & 0 & 5 & 65 & 2 & 72 & 28 & Coridothymus capitatus \\
\hline 5 & Kokkinos Lakos & 10 & 25 & 50 & 2 & 87 & 13 & Coridothymus capitatus \\
\hline 6 & Liziana & 0 & 0 & 5 & 55 & 60 & 40 & Psoralea bituminosa \\
\hline 7 & Liziana & 0 & 0 & 90 & 1 & 91 & 9 & Coridothymus capitatus \\
\hline 8 & Kokkinos Lakos & 5 & 50 & 30 & 5 & 90 & 10 & Coridothymus capitatus \\
\hline 9 & Galaniana & 0 & 0 & 0 & 85 & 85 & 15 & Oxalis sp. \\
\hline 10 & Galaniana & 0 & 0 & 95 & 5 & 100 & 0 & Sarcopoterium spinosum \\
\hline 11 & Charchaliana & 0 & 0 & 64 & 1 & 65 & 35 & Coridothymus capitatus \\
\hline 12 & Charchaliana & 0 & 0 & 0 & 65 & 65 & 35 & Plantago lagopus \\
\hline 13 & Agios Georgios & 0 & 0 & 3 & 62 & 65 & 35 & Oxalis sp. \\
\hline
\end{tabular}

Table 6. Estimated \% cover in the quadrats for each vegetation group (and including bare ground), together with the dominant taxon in each plot 